\title{
Finding insights of Pancreas development
}

\author{
Dr. N.K. Dhakad ${ }^{1}$, Dr. Vipulkeerti Sharma ${ }^{2}$, Ankit Kumar Jain ${ }^{2} *$, \\ Sachin Rahangdale ${ }^{3}$ \\ 1: Additional Director Higher Education, Indore Division, Madhya Pradesh, INDIA \\ 2: Government Holkar Science College, Indore, Madhya Pradesh, INDIA \\ 3: Govt. Madhav Science College, Ujjain, Madhya Pradesh, INDIA
}

\begin{abstract}
Pancreas is organ which contains digestive enzymes that assist the absorption of nutrients to be digested by small intestine which makes this gland as main energy regulator which up regulates expression to counter metabolism or down regulates in promoting or maintaining blood pressure etc. It is made up of exocrine and endocrine parts which have enzymes \& millions of cells regulating its tissue specific expression. Multiple pathways too are associated with pancreatic mechanism which is directly epicenter in modulating energy mechanism throughout organism behavior. We in present study, wants to find out mechanism of pancreatic development with its signaling. Pancreatic beta cell, alpha cell, delta cells, pp cells and all endocrine part is mainly develops by differentiation of PDX gene which further divides and interacts with other differentiation factors of genes which promoted maintenance and development of Islets of Langerhans. We have identified Driver genes involved in this mechanism with their interacting passenger genes which are associated in development of Langerhans. Although, we to have created driver genes interactome of all drivers in development with their respective passengers. For analyses of gene expression we have modeled all gene expression to know their function at proteomic level with this we know that what will be the expression scenario of multiple proteins at structure level. We have used many system biological tools like Cytoscape, Modeller, Grommacs with online tools such as Castp, Phyre2, ifold etc.
\end{abstract}

Key words: Pancreas development, Pdx, Islets of Langerhans, Cytoscape, Modeller, Castp.

\section{Introduction}

The pancreas is a compound gland that consists of two functionally and morphologically distinct cell populations derived from the endoderm. The exocrine pancreas consists of enzyme secreting acinar cells arranged into clusters at the end of the ducts. Mature duct cells actively secrete bicarbonate and mucins, as well as having a more mundane plumbing function of draining acinar digestive enzymes towards the duodenum (Slack, 1995). The endocrine compartment of the pancreas comprises five different hormone secreting cell types: the glucagon secreting a-cell, insulin-secreting b-cell, somatostatin-releasing d-cell, ghrelin-producing ecell, and finally the pancreatic polypeptide-secreting PP-cells. All of these hormones are involved in regulating nutrient metabolism and glucose homeostasis. The endocrine cells aggregate to form the islets of Langerhans, which are intermingled with blood vessels, neurons, and a mesodermally-derived stromal component. The intimate interaction between endocrine and vascular cells regulates hormone release, establishing a fine-tuned glucose homeostasis in the body (Slack, 1995; Prado et al., 2004, Konstantinova et al., 2007). Events are commonly mediated by extrinsic signals from adjacent mesodermal derivatives, as well as by intrinsic programs controlled by factors expressed within the endodermal cells themselves. In the case of the dorsal bud, the dorsal pancreatic region first receives inductive signals from the mesoderm during gastrulation, then permissive signals from the nearby notochord, dorsal aorta, and finally proliferative signals from the pancreas mesenchyme. Compared to the dorsal pancreas, the ventral pancreas is patterned by distinct sets of signals from the lateral plate mesoderm, cardiac mesoderm, and septum transversum.

\section{Material And Methodology}

1. Literature survey: We used PubMed and many more Literature resources to collect research papers and relevant information about mechanism of pancreatic development with its signaling. We have given Priority to information derived from the research literature. Pancreas oganogenesis comprises a coordinated and highly complex interplay of signaling events and transcriptional networks that guide a step-wise process of organ development from early bud specification all the way to the final mature organ state. 


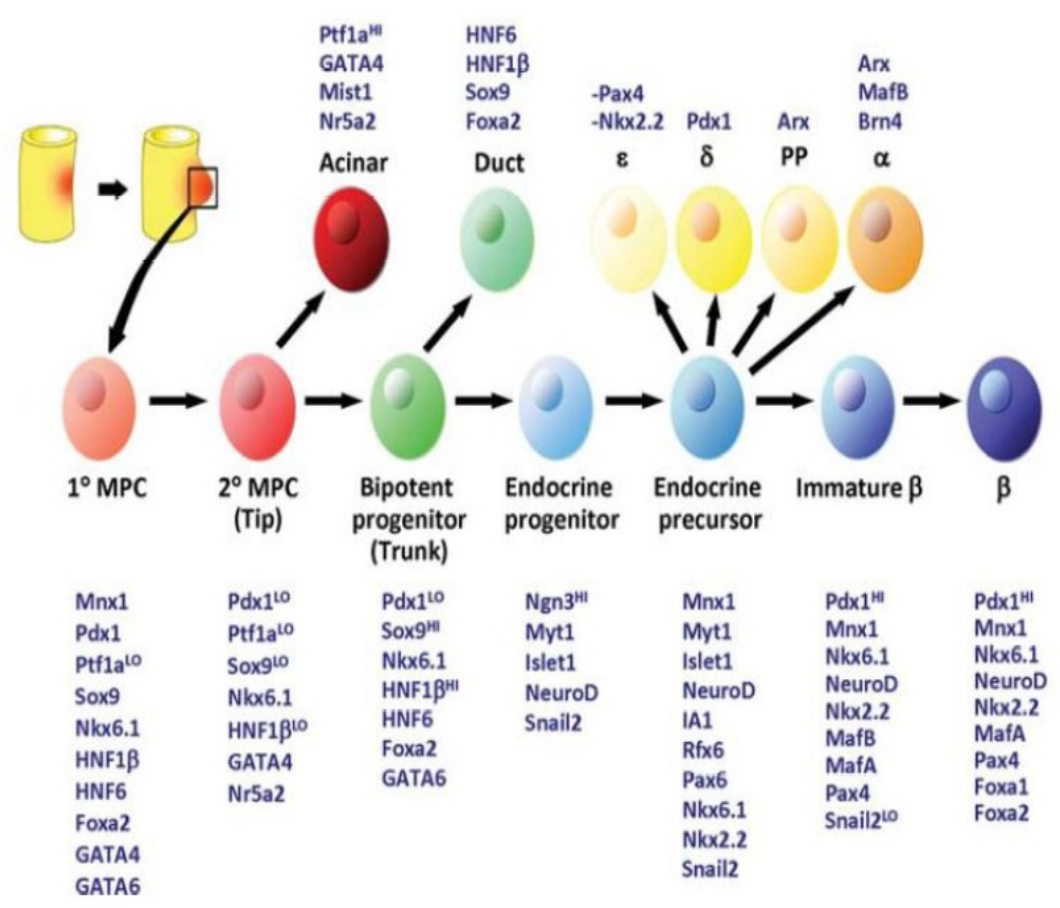

Figure: Important transcriptional regulators expressed at each stage of pancreas development. Pax4 and

Nkx2.2 indicates that e-cells develop in the absence of Pax4 and Nkx2.2.

2. Protein protein interaction: Cytoscape is an Open Source Platform for Complex Network Analysis and Visualization. We used Cytoscape to analysis different gene-gene interaction in Pancreas development at proteomic level and find out Interaction network of the proteins and protein complexes involved into protein transport and exocytosis in the islet cells.

3. Molecular Modeling \& Dynamics Analysis: Metabolic pathway information was obtained from the pathway database Kyoto Encyclopedia of Genes and Genomes. Enzyme commission numbers (EC) of all enzymes involves in pathway was extracted from the KEGG database. Identified genes involved in pathway progression in up regulation and down regulation metabolites synthesis for analyses mechanism at proteomic level (structure \& dynamics) protein modeling is been done in order to find different ligands binding sites, activation sites and venerable sites of all expressed gene at protein level. The amino acid sequence of all enzymes from different sources was retrieved from the protein database of National Center of Biotechnology Information (NCBI, http://www.ncbi.nlm.nih.gov/) with functional annotation from Uniprot. Many enzymes three-dimensional structure of the protein was not yet available in Protein Data Bank and Modbase Database. BLASTP search was performed against Brookhaven Protein Data Bank (PDB) with the default parameters to find suitable templates for homology modeling. The academic version of MODELLER9.10 (http//:www.salilab.org/modeller) was used for 3D structure generation based on the information obtained from sequence alignment. The MODELLER software employs probability density functions as the spatial restraints rather than energy. The 3D model of a protein is obtained by optimization of the molecular such that the model violates the input restraints as possible. The molecule was derived as a combination of restraining individual spatial features of the whole molecule. Different automated servers for tertiary protein structure were utilized such as Phyre2, Protein Jigsaw, I-tasser.

3.1Model Assessment: In all cases the best G-score of PROCHECK (Rampage server) and with the best VERIFY3D profile was subjected to energy minimization. VERIFY3D (a structure evaluation server) was used to check the residue profiles of the obtained three dimensional models. In order to assess the stereo-chemical qualities of the three dimensional models, PROCHECK analysis was performed. Quality evaluation of the model for the environment profile was also predicted using ERRAT structure evaluation server. The final refined model was evaluated for its atomic contacts using the Whatif program to identify bad packing of side chain atoms or unusual residue contacts. The predicted model was also analyzed for the recognition of errors in the three dimensional structure by using the ProSA web server. This model was further subjected for identification of active site and docking study. With the aim of evaluating the stability and folding, conformational changes and getting insights into the natural dynamics on different timescale of protein in solution, 10 nanoseconds (ns) molecular dynamics simulation were performed. The molecular dynamics (MD) 
simulations of all modeled enzymes were carried out with the GROMACS 4.0.6 software package by employing GROMOS 96 force field and the flexible SPC (Simple Point Charge) water model. The initial structure was immersed in a periodic water box of cubic shape $(0.5 \mathrm{~nm}$ thick). Electrostatic energy was calculated using the particle mesh Ewald method. Cutoff distance for the calculation of the coulomb and vander Waals interaction was 1.0 Á. After energy minimization using a steepest descent for 1000 steps, the system was subjected to equilibration at 300k and normal pressure for $100 \mathrm{ps}$ under the conditions of position restraints for heavy atoms. LINCS constraints were performed for all bonds, keeping the whole protein molecule fixed and allowing only the water molecule to move to equilibrate with respect to the protein structure. The system was coupled to the external bath by the Berendsen pressure and temperature coupling. The final MD calculations were performed for $10 \mathrm{~ns}$ under the same conditions except that the position restraints were removed. The results were analyzed using the standard software provided by the GROMACS package. An average structure was refined further using a steepest descent energy minimization. Online automated server to been used for energy minimization by YASARA software/server.

3.2 Active Site Prediction: Binding site was characterized by CASTp and Molegro Virtual Docker and were compared by using the information of binding sites. By comparing prediction of above two algorithms, best active site was selected. The MMFF94 force field was used for energy minimization of active folds of protein molecules. Gasteiger partial charges were added to the ligand atoms, non-polar hydrogen atoms were merged and rotatable bonds were defined. Proteins geometries and electric properties were calculated using MOPAC optimizer program.

4. Molecular Dynamics Simulation: The predicted Model of our proteins has shown good accuracy of the structure. But in order to use this model for virtual screening predicted model should have stable molecular dynamic behavior. The molecular dynamic stability has been established by performing the molecular dynamic simulation study using GROMACS 4.0.6 software package. The root mean square deviation (RMSD) during the simulation was increasing in the beginning but after $220 \mathrm{ps}$ it becomes almost constant for rest of the duration of the simulation. For different enzymes different cut offs were suggested less RMSD for the backbone and which can provide less flexibility, indicating that model has a stable dynamic behavior structure. Molecular dynamic simulation study showed that the energy of the molecule was found to be constant throughout the time period of simulation. This suggests that the molecule has a stable structure as required for the virtual screening and drug designing. The root mean square (RMS) fluctuations were very less. Most the atoms were free from the RMS fluctuations. For all enzymes very few atoms have shown RMS fluctuation at $\mathrm{C}$ and $\mathrm{N}$ terminal due to the loop region. The simulation studies also indicated that radius of gyration was increasing in the beginning but after $400 \mathrm{ps}$ it decreases upto $420 \mathrm{ps}$ and finally became almost constant for rest of the duration of the simulation.

4.1Model Assessment and Refinement: All Proteins were modeled and validated by using the SAVS and PROSA server. Ramachandran plots were drawn and the structures were analyzed by PROCHECK, a wellknown protein structure checking program. By comparison of the results for all the models from different servers and from Modeller9.10, each structure above 92\% accuracy was selected in order to run optimized protein dynamics with their respective simulation. All these findings suggest a stereo chemically very good model. The overall PROCHECK $G$ factor for the homology-modeled structure was 0.00 . The energetic architecture as predicted by PROSA score was negative $(-9.62)$ for all the modeled protein. The value is close to that of template (-9.60), which indicates the reliability of the model. The final structure was validated by an ERRAT graph. The quality factor of 77.106 indicated good quality, as scores of $>50$ are acceptable for a reasonable model. High quality of model is also confirmed from VERIFY 3D server as $86.00 \%$ of residues of modeled protein showed a score higher than 0.02 thus the model showed satisfactory 3D-1D scores for all the residues in the sequence. Results of WHAT_CHECK also indicate about the correctness of the modeled structure. These results indicate that the obtained structure has reasonably good quality.

\section{Results}

We have done Go Biological Process Annotation using tree main filters- transcription, translation and post translation modification, and find out main proteins involved in mechanism of pancreatic development. We find out mechanism of pancreatic development with its signaling. Pancreatic beta cell, alpha cell, delta cells, pp cells and all endocrine part is mainly develops by differentiation of PDX gene which further divides and interacts with other differentiation factors of genes which promoted maintenance and development of Islets of Langerhans. We have identified Driver genes involved in this mechanism with their interacting passenger genes which are associated in development of Langerhans. Although, we to have created driver genes interactome of all drivers in development with their respective passengers. For analyses of gene expression we have modeled 
all gene expression to know their function at proteomic level with this we know that what will be the expression scenario of multiple proteins at structure level.

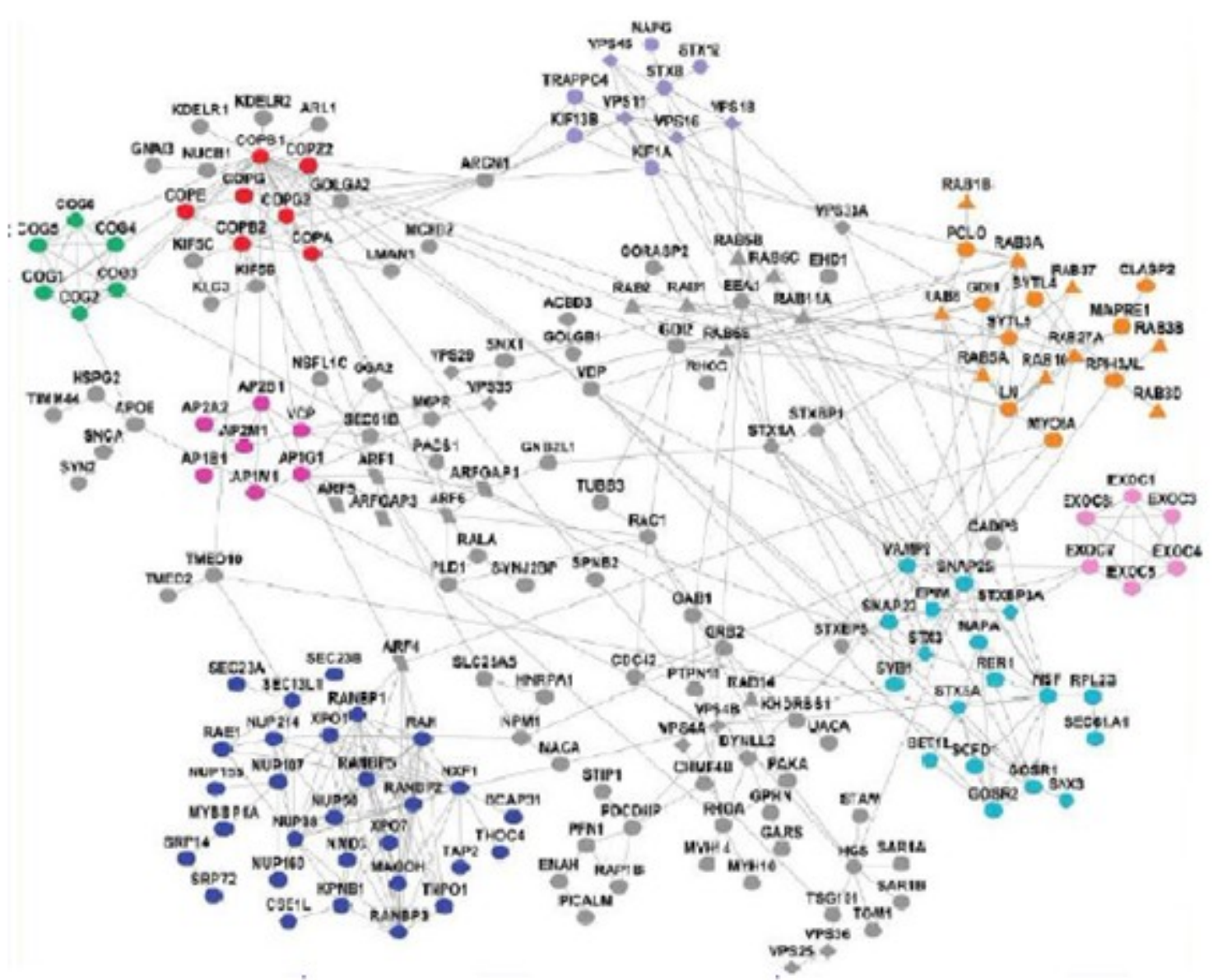

Figure 1: Interaction network of the proteins and protein complexes involved into protein transport and exocytosis in the islet cells. Proteins from overrepresented GO terms were analyzed using Cytoscape plug-in CABIN to build the protein-protein interaction network. The eight clusters are oligomeric Golgi complex (green), coatomer complex (red), cluster containing vacuolar protein sorting proteins and syntaxins 8 and 12 (light blue), cluster of Rab GTPases (orange), exocyst complex (light pink), SNARE comples (turquoise), cluster mostly consisting of proteins involved in the transport via the nuclear membrane (blue) and cluster of adaptor proteins such as VCP (bright pink). Several of the highly representative functional categories were abeled with distinct shapes other than the default round node shape. GTPases such as Rab and Arf involved in the regulation of trafficking are shown with triangles and parallelograms, respectively. Syntaxins involved in fusion of synaptic vesicles with plasma membrane are shown as hexagon shape. Vacuolar protein sorting proteins are shown as diamonds.

Table: Molecular Dynamics Based Energy Confirmation

\begin{tabular}{|l|l|l|l|}
\hline S.No & \multicolumn{1}{|c|}{ Protein Name } & \multicolumn{1}{c|}{ Start } & \multicolumn{1}{c|}{ End } \\
\hline 1 & $\begin{array}{l}\text { Alpha:Q96QS3|ARX_HUMAN } \\
\text { Homeobox protein ARX (ARX) }\end{array}$ & $\begin{array}{l}\text { Energy: } \\
-69568.5 \mathrm{kj} / \mathrm{mol} \\
\text { Score: }-2.49\end{array}$ & $\begin{array}{l}\text { Energy: } \\
-158789.3 \mathrm{KJ} / \mathrm{mol} \\
\text { Score: }-0.37\end{array}$ \\
\hline 2 & $\begin{array}{l}\text { Alpha:P49335|PO3F4_HUMAN POU } \\
\text { domain, class 3, transcription factor 4 } \\
\text { (BRN4) }\end{array}$ & $\begin{array}{l}\text { Energy: } 2387452070392540160.0 \mathrm{kj} / \mathrm{mol} \\
\text { Score: }-9.49\end{array}$ & $\begin{array}{l}\text { Energy: } \\
-132973.1 \mathrm{kj} / \mathrm{mol} \\
\text { Score: }-2.49\end{array}$ \\
\hline 3 & Alpha:Q9Y5Q3|MAFB_HUMAN & Energy: & Energy: \\
& Transcription factor MafB (MafB) & $5280516674989920.0 \mathrm{kj} / \mathrm{mol}$ & $-145748.8 \mathrm{kj} / \mathrm{mol}$ \\
& & Score: -9.03 & Score: -5.09 \\
\hline 4 & Beta:Q8NHW3|MAFA_HUMAN & $\begin{array}{l}\text { Energy: } \\
1754.1 \mathrm{kj} / \mathrm{mol}\end{array}$ & Energy: \\
& Transcription factor MafA: & Score: -7.54 & $-145899.1 \mathrm{kj} / \mathrm{mol}$ \\
& & Score: -5.08 \\
\hline 5 & Beta:P50219|MNX1_HUMAN Motor & Energy: & Energy: \\
& neuron and pancreas homeobox protein 1 & $-19829.8 \mathrm{kj} / \mathrm{mol}$ & $-164380.6 \mathrm{kj} / \mathrm{mol}$ \\
& & Score: -7.40 & Score: -4.73 \\
\hline
\end{tabular}


Finding insights of Pancreas development

\begin{tabular}{|c|c|c|c|}
\hline 6 & $\begin{array}{l}\text { Beta:O95096|NKX22_HUMAN } \\
\text { Homeobox protein Nkx-2.2 }\end{array}$ & $\begin{array}{l}\text { Energy: } \\
-9710.4 \mathrm{kj} / \mathrm{mol} \\
\text { Score: }-6.34 \\
\end{array}$ & $\begin{array}{l}\text { Energy: } \\
-118253.6 \mathrm{kj} / \mathrm{mol} \\
\text { Score: }-3.89 \\
\end{array}$ \\
\hline 7 & $\begin{array}{l}\text { Beta:P78426|NKX61_HUMAN } \\
\text { Homeobox protein Nkx-6.1 }\end{array}$ & $\begin{array}{l}\text { Energy: } \\
-19829.8 \mathrm{kj} / \mathrm{mol} \\
\text { Score: }-7.40\end{array}$ & $\begin{array}{l}\text { Energy: } \\
-164380.6 \mathrm{kj} / \mathrm{mol} \\
\text { Score: }-4.73\end{array}$ \\
\hline 8 & $\begin{array}{l}\text { Beta:O43316|PAX4_HUMAN } \\
\text { box protein Pax-4 }\end{array}$ & $\begin{array}{l}\text { Energy: } \\
\text { 13867746701357.8kj/mol } \\
\text { Score: }-9.67\end{array}$ & $\begin{array}{l}\text { Energy: } \\
-121304.2 \mathrm{kj} / \mathrm{mol} \\
\text { Score: }-5.09 \\
\end{array}$ \\
\hline 9 & $\begin{array}{l}\text { Beta:Q54J47|PDX1_DICDI } \\
\text { Probablepyridoxine biosynthesis protein } \\
\text { pdx1 }\end{array}$ & $\begin{array}{l}\text { Energy: } \\
-4065.2 \mathrm{kj} / \mathrm{mol} \\
\text { Score: }-6.33\end{array}$ & $\begin{array}{l}\text { Energy: } \\
-141098.5 \mathrm{kj} / \mathrm{mol} \\
\text { Score: }-3.15\end{array}$ \\
\hline 10 & $\begin{array}{l}\text { Beta:P55317|FOXA1_HUMAN } \\
\text { Hepatocyte nuclear factor 3-alpha }\end{array}$ & $\begin{array}{l}\text { Energy: } \\
\text { 103755803973600.0kj/mol } \\
\text { Score: }-8.25\end{array}$ & $\begin{array}{l}\text { Energy: } \\
-131066.7 \mathrm{kj} / \mathrm{mol} \\
\text { Score: }-3.87 \\
\end{array}$ \\
\hline 11 & $\begin{array}{l}\text { Beta:Q9Y261|FOXA2_HUMAN } \\
\text { Hepatocyte nuclear factor 3-beta }\end{array}$ & $\begin{array}{l}\text { Energy: } \\
135159.6 \mathrm{kj} / \mathrm{mol} \\
\text { Score: }-6.20\end{array}$ & $\begin{array}{l}\text { Energy: } \\
-119740.3 \mathrm{kj} / \mathrm{mol} \\
\text { Score: }-2.50\end{array}$ \\
\hline 12 & $\begin{array}{l}\text { PPcells: Q96QS3|ARX_HUMAN } \\
\text { Homeobox protein ARX (ARX) }\end{array}$ & $\begin{array}{l}\text { Energy: } \\
-69568.5 \mathrm{kj} / \mathrm{mol} \\
\text { Score: }-2.49 \\
\end{array}$ & $\begin{array}{l}\text { Energy: } \\
-18789.3 \mathrm{kj} / \mathrm{mol} \\
\text { Score: }-0.37 \\
\end{array}$ \\
\hline 13 & $\begin{array}{l}\text { Delta: Q54J47|PDX1_DICDI } \\
\text { Probablepyridoxine biosynthesis protein } \\
\text { pdx1 }\end{array}$ & $\begin{array}{l}\text { Energy: } \\
-4065.2 \mathrm{kj} / \mathrm{mol} \\
\text { Score: }-6.33\end{array}$ & $\begin{array}{l}\text { Energy: } \\
-141098.5 \mathrm{kj} / \mathrm{mol} \\
\text { Score: }-3.15\end{array}$ \\
\hline 14 & $\begin{array}{l}\text { Epsilon: } \quad \text { O95096|NKX22_HUMAN } \\
\text { Homeobox protein } \mathrm{Nkx}-2.2\end{array}$ & $\begin{array}{l}\text { Energy: } \\
-9710.4 \mathrm{kj} / \mathrm{mol} \\
\text { Score: }-6.24 \\
\end{array}$ & $\begin{array}{l}\text { Energy: } \\
-118253.6 \mathrm{kj} / \mathrm{mol} \\
\text { Score: }-3.89 \\
\end{array}$ \\
\hline 15 & $\begin{array}{l}\text { Epsilon: O43316|PAX4_HUMAN Paired } \\
\text { box protein Pax-4: }\end{array}$ & $\begin{array}{l}\text { Energy: } \\
\text { 13867746701357.8kj/mol } \\
\text { Score: }-9.67\end{array}$ & $\begin{array}{l}\text { Energy: } \\
-121304.2 \mathrm{kj} / \mathrm{mol} \\
\text { Score: }-5.09\end{array}$ \\
\hline 16 & $\begin{array}{l}\text { Epsilon: } \\
\text { O43316-2|PAX4_HUMAN Isoform } 2 \text { of } \\
\text { Paired box protein Pax-4 }\end{array}$ & $\begin{array}{l}\text { Energy: } \\
\text { 530576788335204.0kj/mol } \\
\text { Score: }-8.55 \\
\end{array}$ & $\begin{array}{l}\text { Energy: } \\
-141046.9 \mathrm{kj} / \mathrm{mol} \\
\text { Score: }-4.21 \\
\end{array}$ \\
\hline 17 & $\begin{array}{l}\text { Epsilon: } \\
\text { O43316-4|PAX4_HUMAN Isoform } 3 \text { of } \\
\text { Paired box protein Pax-4 }\end{array}$ & $\begin{array}{l}\text { Energy: } \\
\text { 6798450688040930.0kj/mol } \\
\text { Score: }-9.41\end{array}$ & $\begin{array}{l}\text { Energy: } \\
-214682.6 \mathrm{kj} / \mathrm{mol} \\
\text { Score: }-5.16\end{array}$ \\
\hline
\end{tabular}

\section{Discussion}

Research associated with pancreas development is largely driven by a translational potential for pancreatic diseases such as diabetes \& pancreatic cancer. transcriptional and signaling codes that control the entire organogenesis process, allowing us to apply this knowledge in a therapeutic context, by generating replacement cells in vitro, or perhaps one day to the whole organ in vivo. Pancreas differentiation process To be able to be unwound in a regulated fashion, or redirected, and suggest linkages to the possible reprogramming of other pancreatic cell-types in vivo, and to the optimization of the forward directed- differentiation of human embryonic stem cells or induced pluripotential cells towards mature b-cells. So we have tried to analysis mechanism behind Pancreas development and its process of cell differentiation. We find drive and passenger involved in gene-gene interaction \& gene-protein interaction. In both case i.e. Drivers and passenger involved in Pancreas development with possible signaling regulators. We also tried to understand Proteomic level expression scenario of different drivers with their passengers involved in development of Islets of Langerhans

\section{Conclusions}

We in this interactome study have founded many facets which correlated with different dimensions of Islets of Langerhans development. Evaluation of around 2300 gene interaction have revealed many passengers involved in dynamicity of Beta cells, alpha cells, pp cells, delta cell, epsilon cell.

\section{Main Points Of Our Study}

1. MafA expression in liver together with Pdx1 and NeuroD1 induces insulin gene transcription and provide glucose tolerance in animal interactomics.

2. MafA, Pdx1 \& NeuroD1 can be implied by a combine therapy in terms of manipulation. As, it will be useful for replacing the reduced Beta cell function found in Diabetes.

3. MafA may be a novel therapeutic target for Diabetes as it is a potential activator of insulin gene transcription, Too, it is the only Beta cell specific trans-activator for the insulin gene.

4. Sox9 is involved in proliferation, survival and maintenance of pancreatic progenitors. With controlled epicenter as a main Broadcast center in regulation of signaling in beta as well in alpha cell metabolism.

5. Pdx1 is a major trans-activator of Insulin gene with other islets specific genes such as: GLUT 2, GLUCOKINASE, IAPP, SOMATOSTATIN. 
6. Pdx1 can be directly activated by transcription factors: NeuroD1, Hnfla, Hnflb.

7. NeuroD1 also regulates the transcription of the insulin gene.

\section{Acknowledgment}

The authors are thankful to Dr. R K Tugnawat, Principal Govt. Holkar Science College, Indore for his constant encouragement.

\section{References}

[1]. Ahlgren, U., Jonsson, J., Jonsson, L., Simu, K., and Edlund, H. (1998). beta-cell-specific inactivation of the mouse Ipf1/Pdx1 gene results in loss of the beta-cell phenotype and maturity onset diabetes. Genes Dev 12, 1763-1768.

[2]. Aird, W. C., Edelberg, J. M., Weiler-Guettler, H., Simmons, W. W., Smith, T. W., and Rosenberg, R. D. (1997). Vascular bedspecific expression of an endothelial cell gene is programmed by the tissue microenvironment. J Cell Biol 138, 1117-1124.

[3]. Doi, M., Thyboll, J., Kortesmaa, J., Jansson, K., Iivanainen, A., Parvardeh, M., Timpl, R., Hedin, U., Swedenborg, J., and Tryggvason, K. (2002). Recombinant human laminin-10 (alpha5beta1gamma1). Production, purification, and migration-promoting activity on vascular endothelial cells. J Biol Chem 277, 12741-12748.

[4]. Dor, Y., Brown, J., Martinez, O. I., and Melton, D. A. (2004). Adult pancreatic beta cells are formed by selfduplication rather than stem cell differentiation. Nature 429, 41-46.

[5]. Edlund, H. (2002). Pancreatic organogenesis--developmental mechanisms and implications for therapy. Nat Rev Genet 3, 524-532.

[6]. Edvell, A., and Lindstrom, P. (1999). Initiation of increased pancreatic islet growth in young normoglycemic mice (Umea $+/$ ?). Endocrinology 140, 778-783.

[7]. Finegood, D. T., Scaglia, L., and Bonner-Weir, S. (1995). Dynamics of beta-cell mass in the growing rat pancreas. Estimation with a simple mathematical model. Diabetes 44, 249-256.

[8]. Hammar, E. B., Irminger, J. C., Rickenbach, K., Parnaud, G., Ribaux, P., Bosco, D., Rouiller, D. G., and Halban, P. A. (2005). Activation of NF-kappaB by extracellular matrix is involved in spreading and glucose-stimulated insulin secretion of pancreatic beta cells. J Biol Chem 280, 30630-30637.

[9]. Hanahan, D., and Folkman, J. (1996). Patterns and emerging mechanisms of the angiogenic switch during tumorigenesis. Cell 86, 353-364.

[10]. Hellerstrom, C., Swenne, I., and Eriksson, U. J. (1985). Is there an animal model for gestational diabetes? Diabetes 34 Suppl 2, 2831.

[11]. Henderson, J. R., and Moss, M. C. (1985). A morphometric study of the endocrine and exocrine capillaries of the pancreas. Q J Exp Physiol 70, 347-356.

[12]. Hill, C. S., and Treisman, R. (1995). Transcriptional regulation by extracellular signals: mechanisms and specificity. Cell 80, 199211 .

[13]. Hill, D. J., and Duvillie, B. (2000). Pancreatic development and adult diabetes. Pediatr Res 48, 269-274.

[14]. Humphries, M. J., McEwan, P. A., Barton, S. J., Buckley, P. A., Bella, J., and Mould, A. P. (2003). Integrin structure: heady advances in ligand binding, but activation still makes the knees wobble. Trends Biochem Sci 28, 313-320.

[15]. Hutley, L. J., Herington, A. C., Shurety, W., Cheung, C., Vesey, D. A., Cameron, D. P., and Prins, J. B. (2001).

[16]. Inoue, M., Hager, J. H., Ferrara, N., Gerber, H. P., and Hanahan, D. (2002). VEGF-A has a critical, nonredundant role in angiogenic switching and pancreatic beta cell carcinogenesis. Cancer Cell 1, 193-202.

[17]. Jun, H. S., and Yoon, J. W. (2005). Approaches for the cure of type 1 diabetes by cellular and gene therapy. Curr Gene Ther 5, 249262.

[18]. Kataoka, K., Shioda, S., Ando, K., Sakagami, K., Handa, H., and Yasuda, K. (2004). Differentially expressed Maf family transcription factors, c-Maf and MafA, activate glucagon and insulin gene expression in pancreatic islet alpha- and beta-cells. J Mol Endocrinol 32, 9-20.

[19]. Kodama, S., Kuhtreiber, W., Fujimura, S., Dale, E. A., and Faustman, D. L. (2003). Islet regeneration during the reversal of autoimmune diabetes in NOD mice. Science 302, 1223- 1227.

[20]. LeCouter, J., Kowalski, J., Foster, J., Hass, P., Zhang, Z., Dillard-Telm, L., Frantz, G., Rangell, L., DeGuzman, L., Keller, G. A., et al. (2001). Identification of an angiogenic mitogen selective for endocrine gland endothelium. Nature 412, 877-884.

[21]. L. (2001). Compensatory responses in mice carrying a null mutation for Ins1 or Ins2. Diabetes 50 Suppl 1, S150- 153. Letters to the editor (1999). Diabetes research and clinical practice.

[22]. Majumdar, A., and Drummond, I. A. (1999). Podocyte differentiation in the absence of endothelial cells as revealed in the zebrafish avascular mutant, cloche. Dev Genet 24, 220-229.

[23]. Markussen, J., Heding, L. G., Jorgensen, K. H., and Sundby, F. (1971). Proinsulin, insulin and C-peptide. Horm Metab Res 3, Supp1 3:33-35.

[24]. Marshak, S., Benshushan, E., Shoshkes, M., Leibovitz, G., Kaiser, N., Gross, D., Bertuzzi, F., Cerasi, E., and Melloul, D. (2001). beta-cell-specific expression of insulin and PDX-1 genes. Diabetes 50 Suppl 1, S131-132.

[25]. Marshak, S., Totary, H., Cerasi, E., and Melloul, D. (1996). Purification of the beta-cell glucose-sensitive factor that transactivates the insulin gene differentially in normal and transformed islet cells. Proc Natl Acad Sci U S A 93, 15057-15062.

[26]. Martin, D., Zusman, S., Li, X., Williams, E. L., Khare, N., DaRocha, S., Chiquet-Ehrismann, R., and Baumgartner, S. (1999). wing blister, a new Drosophila laminin alpha chain required for cell adhesion and migration during embryonic and imaginal development. J Cell Biol 145, 191-201.

[27]. Parsons, J. A., Brelje, T. C., and Sorenson, R. L. (1992). Adaptation of islets of Langerhans to pregnancy: increased islet cell proliferation and insulin secretion correlates with the onset of placental lactogen secretion. Endocrinology 130, 1459-1466. 90

[28]. Ruoslahti, E. (2002). Specialization of tumour vasculature. Nat Rev Cancer 2, 83-90.

[29]. Ruoslahti, E., and Pierschbacher, M. D. (1987). New perspectives in cell adhesion: RGD and integrins. Science 238, 491-497.

[30]. Sandler, S., and Andersson, A. (1986). Long-term effects of exposure of pancreatic islets to nicotinamide in vitro on DNA synthesis, metabolism and B-cell function. Diabetologia 29, 199-202.

[31]. Scaglia, L., Smith, F. E., and Bonner-Weir, S. (1995). Apoptosis contributes to the involution of beta cell mass in the post partum rat pancreas. Endocrinology 136, 5461-5468.

[32]. Seid, C. A., Ramachandran, R. K., George, J. M., Govindarajan, V., Gonzalez-Rimbau, M. F., Flytzanis, C. N., and Tomlinson, C. R. (1997). An extracellular matrix response element in the promoter of the LpS1 genes of the sea urchin Lytechinus pictus. Nucleic Acids Res 25, 3175-3182. 
[33]. Sjoholm, A., Welsh, N., and Hellerstrom, C. (1992). Lithium increases DNA replication, polyamine content, and insulin secretion by rat pancreatic beta-cells. Am J Physiol 262, C391-395.

[34]. Smyth, N., Vatansever, H. S., Murray, P., Meyer, M., Frie, C., Paulsson, M., and Edgar, D. (1999). Absence of basement membranes after targeting the LAMC1 gene results in embryonic lethality due to failure of endoderm differentiation. J Cell Biol $144,151-160$

[35]. Taraviras, S., Monaghan, A.P., Schutz, G., Kelsey, G., 1994. Characterization of the mouse HNF-4 gene and its expression during mouse embryogenesis. Mech. Dev. 48, 67-79.

[36]. Teitelman, G., Joh, T.H., Reis, D.J., 1981. Transformation of catecholaminergic precursors into glucagon (A) cells in mouse embryonic pancreas. Proc. Natl. Acad. Sci. USA 78, 5225-5229.

[37]. Teitelman, G., Alpert, S., Polak, J.M., Martinez, A., Hanahan, D., 1993. Precursor cells of mouse endocrine pancreas coexpress insulin, glucagon and the neuronal proteins tyrosine hydroxylase and neuropeptide $\mathrm{Y}$, but not pancreatic polypeptide. Development $118,1031-1039$. 